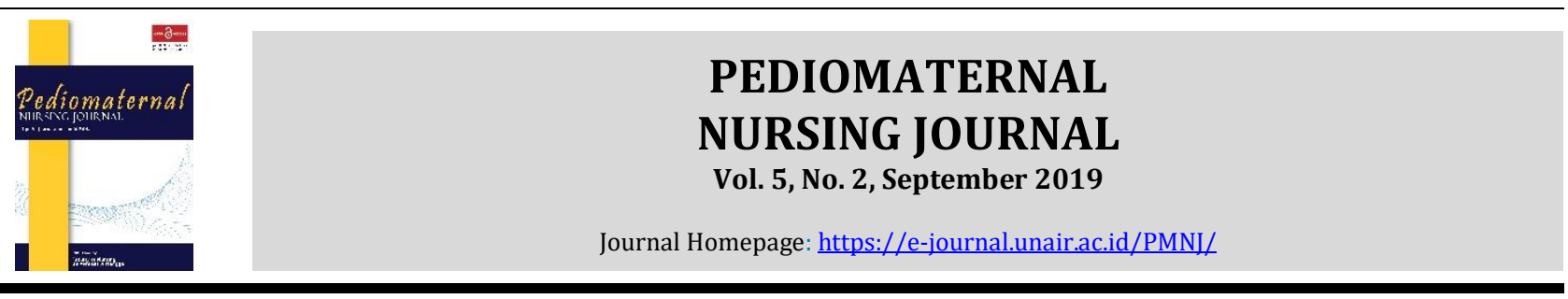

Original Research

\title{
Faktor Risiko Kejadian Atonia Uteri
}

\section{(Risk Factors for Uterine Atonia)}

\author{
Mega Lestari ${ }^{1}$, Pungky Mulawardhana ${ }^{2}$, dan Budi Utomo ${ }^{3}$ \\ ${ }^{1}$ Program Studi Kebidanan Fakultas Kedokteran, Universitas Airlangga, Surabaya, Indonesia \\ ${ }^{2}$ Departemen Obstetri Ginekologi, Universitas Airlangga, Surabaya, Indonesia \\ ${ }^{3}$ Departemen IKM-KP Fakultas Kedokteran, Universitas Airlangga, Surabaya, Indonesia
}

\section{ARTICLE HISTORY}

Received: May 27, 2019

Accepted: July 23, 2019

\section{KEYWORDS}

advanced maternal age; grande multiparity; labour augmented; prolonged labour; uterine overdistension

\section{CORRESPONDING AUTHOR}

Mega Lestari

mega.lestari-

2017@fk.unair.ac.id

Program Studi Kebidanan,

Fakultas Kedokteran,

Universitas Airlangga, Surabaya, Indonesia

\section{Cite this as:}

\begin{abstract}
Introduction: Postpartum Hemorrhage is one of the main cause of maternal morbidity and mortality worlwide. Every 4 minutes one woman is estimated dead by this case. The cause of postpartum hemorrhage is known as ' 4 T's' (tone, tissue, trauma, and thrombin). Common aetiology of hemorrhage postpartum is uterine atony. Uterine atony can be caused by several risk factors. The aim of this study is to determine the correlation between advanced maternal age, grande multiparity, uterine overdistension, labour augmented, and prolonged labour as risk factors with the incidence of uterine atony.
\end{abstract}

Methods: This study was an analysis of observational study with case-control design conducted at a tertiary hospital in Surabaya. The population was all medical record of postpartum women who had hemorrhage in 2016-2018. The case group was postpartum woman who had hemorrhage due to uterine atony and the control group due to other causes. The sample size of the case group was 37 respondents and the control group was 35 respondents, they were obtained through purposive sampling. The independent variables in this study was maternal age, parity, uterine overdistension, labour augmented, and prolonged labour; the dependent variable was uterine atony. Univariate analysis was used to describe respondent's characteristic and bivariate analysis was used to determine the correlation between risk factors and the incidence of uterine atony. Fisher Exact was used to analyze the data with $\alpha=0,05$.

Results: Fisher Exact showed there was correlation between uterine overdistension and uterine atony ( $\mathrm{p}$ value $=0,036$; OR= 4,423; 95\% CI 1,023-27,267) on the other hand it showed no correlation between maternal age, parity, augmented labour, and prolonged labour with uterine atony ( $\mathrm{p}$ value $>0,05$ ).

Conclusion: Increased awareness of pre-conceptual care and early detection of risk factors are needed to reduce the risk factors of the incidence of uterine atony especially in uterine overdistension.

Lestari, M., Mulawardhana, P., \& Utomo, B. (2019). Faktor Risiko Kejadian Atonia Uteri. Pediomaternal Nurs. J., 5(2), 189-196.

\section{PENDAHULUAN}

Kehamilan dan persalinan merupakan proses fisiologis namun tidak menutup kemungkinan untuk terjadi komplikasi. Kematian ibu dapat disebabkan oleh komplikasi pada kehamilan dan persalinan yang sebenarnya dapat dicegah. Kasus kematian ibu terbanyak ditemukan di negara berkembang dengan salah satu penyebab utamanya adalah kasus perdarahan postpartum (WHO, 2018) dan diperkirakan 1 wanita meninggal setiap 4 menit akibat kasus tersebut (1).

Perdarahan postpartum adalah perdarahan yang terjadi melalui jalan lahir melebihi batas normal yaitu $500 \mathrm{ml}$ pada persalinan pervaginam dan 1000 ml pada sectio caesarea, diikuti dengan perubahan tanda vital sebagai akibat dari ketidakstabilan hemodinamik pada perdarahan yang banyak dan adanya penurunan hematokrit. Perdarahan postpartum masif ditujukkan pada pasien yang kehilangan 30\%-40\% volume darah (1). 
Penyebab perdarahan postpartum dibagi menjadi 4 kategori dan dikenal dengan istilah ' $4 \mathrm{~T}$ 's' yang terdiri dari tone (kegagalan uterus untuk berkontraksi), tissue (jaringan plasenta dan bekuan darah yang tertinggal di dalam uterus), trauma (perlukaan pada jalan lahir), dan thrombin (gangguan pembekuan darah) (1-3). Atonia uteri merupakan penyebab perdarahan hebat postpartum dari kategori tone yang paling umum ditemukan yaitu sebesar $60 \%-80 \%(1,4)$.

Atonia uteri merupakan kegagalan otot rahim dalam melakukan kompresi pembuluh darah pada sisi plasenta yang terbuka setelah terjadi separasi, sehingga darah dalam jumlah besar mengalir dari pembuluh darah maternal tanpa dapat dihentikan melalui fungsi hemostasis dan kerja ligatur (Fraser dan Cooper, 2011; Cunningham, 2018). Perdarahan berat akibat dari atonia uteri selain dapat meningkatkan angka mortalitas maternal juga dapat meningkatkan angka morbiditas meliputi anemia berat yang menyebabkan ibu memerlukan transfusi darah, kurangnya perfusi jaringan sehingga terjadi kegagalan organ, dan tindakan operatif invasif berupa $B$-Lynch sampai dengan histerektomi $(1,4,5)$.

Atonia uteri disebabkan oleh berbagai faktor risiko yang dapat dibagi menjadi faktor risiko pada antepartum dan intrapartum. Faktor risiko antepartum terdiri dari anemia sejak masa kehamilan $(\mathrm{Hb} \leq 9 \mathrm{gr} / \mathrm{dl})$, peningkatan umur ibu, grande multipara, distensi uterus berlebih (kehamilan kembar, makrosomia, polihidramnion), dan riwayat perdarahan postpartum sedangkan faktor risiko pada intrapartum terdiri dari anestesi umum, percepatan persalinan, persalinan lama, kala 3 memanjang, dan partus precipitatus $(1,2,4)$.

\section{METODE}

\subsection{Desain}

Penelitian ini adalah penelitian analitik observasional dengan pendekatan case control.

\subsection{Populasi, sampel, dan sampling}

Penelitian ini dilakukan di Ruang X RS Y Surabaya dengan besar populasi penelitian sebanyak 131 rekam medik pasien perdarahan postpartum selama periode tahun 2016-2018. Sampel yang ditemukan dengan teknik purposive sampling adalah sebanyak 37 rekam medik untuk kelompok kasus dan 35 rekam medik untuk kelompok kontrol yang sesuai kriteria inklusi dan eksklusi. Kelompok kasus adalah rekam medik ibu yang mengalami perdarahan postpartum karena atonia uteri sedangkan kelompok kontrol adalah rekam medik ibu yang mengalami perdarahan postpartum karena sebab lain yaitu dari faktor tissue, trauma, dan thrombin. Total sampel pada penelitian ini adalah sebanyak 72 rekam medik dengan perbandingan kelompok kasus dan kelompok kontrol 1:1. Waktu pelaksanaan penelitian yaitu antara bulan September 2018 sampai dengan Mei 2019. Pengambilan dan pengumpulan data dilakukan pada bulan Januari 2019 sampai dengan April 2019.

\subsection{Variabel}

Variabel independen pada penelitian ini terdiri dari umur ibu, paritas, distensi uterus berlebih, dan partus lama sedangkan variabel dependen adalah atonia uteri.

\subsection{Instrumen}

Lembar Pengumpul Data (LPD) digunakan sebagai instrumen pada penelitian ini untuk mengambil data sekunder yaitu data dari rekam medik.

\subsection{Prosedur}

Proses pengumpulan data dilakukan setelah surat izin persetujuan penelitian diperoleh dari bagian akademik Program Studi Kebidanan Fakultas Kedokteran Universitas Airlangga dan RSUD Y Surabaya. Tahapan pengumpulan data diawali dengan penetapan nomor rekam medik ibu post partum yang sesuai kriteria inklusi dan eksklusi melalui buku register di Ruang X RSUD Y Surabaya. Nomor rekam medik tersebut kemudian digunakan sebagai acuan untuk mendapatkan rekam medik yang diinginkan sebagai sumber data yang dimasukkan ke dalam lembar LPD.

\subsection{Analisis}

Analisis univariat digunakan untuk menggambarkan karakteristik dari responden penelitian yang berupa distribusi frekuensi dan persentase dari masingmasing variabel. Uji Fisher Exact digunakan pada analisis bivariat untuk mengetahui hubungan kemaknaan antara variabel faktor risiko dengan kejadian atonia uteri dengan bantuan aplikasi Program EZR dengan derajat signifikasi $\alpha=0,05$.

\subsection{Ethical Clearance}

Ethical clearance yang digunakan yaitu kelaikan etik yang didapatkan dari tim komite etik penelitian kesehatan RSUD Y Surabaya dengan nomor sertifikat kelaikan etik yaitu 0881/KEPK/XII/2018. Pengambilan data dilakukan dengan mengikuti prinsip anonimity dan confidentialy untuk menjaga kerahasiaan pasien.

\section{Hasil}

Hasil analisis univariat didapatkan karakteristik ibu yang mengalami perdarahan postpartum karena atonia uteri sebagian besar berada di usia reproduksi sehat, yaitu umur 20-35 tahun sebanyak 27 responden (73\%), memiliki pekerjaan sebanyak 29 responden $(78,4 \%)$, dan bersalin secara sectio caesarea sebanyak 25 responden $(67,6 \%)$. Hampir seluruh responden yang mengalami atonia uteri memiliki tingkat pendidikan SMA yaitu sebanyak 33 responden $(89,2 \%)$, memiliki paritas $<5$ sebanyak 36 responden $(97,3 \%)$, dan tidak memiliki riwayat perdarahan postpartum sebanyak 35 responden $(94,6 \%)$ serta sebagian responden mendapat terapi MgSO4 sebanyak 18 responden (48,6\%) [Tabel 1].

Karakteristik lainnya merupakan tindakan penanganan perdarahan postpartum. Beberapa 
Tabel 1. Karakteristik Maternal yang Mengalami Perdarahan Postpartum (n=72)

\begin{tabular}{|c|c|c|c|c|}
\hline \multirow{3}{*}{ Variabel } & \multicolumn{4}{|c|}{ Perdarahan Postpartum } \\
\hline & \multicolumn{2}{|c|}{ Kasus } & \multicolumn{2}{|c|}{ Kontrol } \\
\hline & $\mathbf{n}=\mathbf{3 7}$ & $\%$ & $n=35$ & $\%$ \\
\hline \multicolumn{5}{|l|}{ Umur } \\
\hline$<20$ tahun & 1 & 2,7 & 0 & 0 \\
\hline 20-35 tahun & 27 & 73 & 21 & 60 \\
\hline$>35$ tahun & 9 & 24,3 & 14 & 40 \\
\hline \multicolumn{5}{|l|}{ Pendidikan } \\
\hline Tidak sekolah & 0 & 0 & 0 & 0 \\
\hline SD & 0 & 0 & 0 & 0 \\
\hline SMP & 1 & 2,7 & 1 & 2,9 \\
\hline SMA & 33 & 89,2 & 28 & 80 \\
\hline Akademi/ Perguruan Tinggi & 2 & 5,4 & 3 & 8,6 \\
\hline Lain-lain & 1 & 2,7 & 3 & 8,6 \\
\hline \multicolumn{5}{|l|}{ Pekerjaan } \\
\hline Tidak Bekerja & 8 & 21,6 & 14 & 40 \\
\hline Bekerja & 29 & 78,4 & 21 & 60 \\
\hline \multicolumn{5}{|l|}{ Paritas } \\
\hline$<5$ & 36 & 97,3 & 35 & 100 \\
\hline$\geq 5$ & 1 & 2,7 & 0 & 0,0 \\
\hline \multicolumn{5}{|l|}{ Riwayat HPP } \\
\hline Tidak & 35 & 94,6 & 34 & 97,1 \\
\hline Ya & 2 & 5,4 & 1 & 2,9 \\
\hline \multicolumn{5}{|l|}{ Cara Persalinan } \\
\hline Persalinan pervaginam & 12 & 32,4 & 9 & 25,7 \\
\hline $\mathrm{SC}$ & 25 & 67,6 & 26 & 74,3 \\
\hline \multicolumn{5}{|l|}{ Pemberian MgSO4 } \\
\hline Tidak & 19 & 51,4 & 31 & 88,6 \\
\hline $\mathrm{Ya}$ & 18 & 48,6 & 4 & 11,4 \\
\hline
\end{tabular}

tindakan seperti kompresi bimanual, B-Lynch, dan ballon tamponade merupakan tindakan karakteristik untuk kasus perdarahan yang berasal dari faktor tonus, namun tindakan seperti kuretase merupakan karakteristik tindakan perdarahan dari sebab lain yaitu faktor tissue. Pada kelompok kasus diketahui hampir seluruh responden mendapatkan pemberian uterotonika yaitu sebanyak 36 responden (97,3\%) dan injeksi asam traneksamat sebanyak 31 responden $(83,8 \%)$ sebagai terapi medikamentosa dan metode konservatif konvensional dalam menghentikan terjadinya perdarahan. Tindakan konservatif lainnya pada kelompok kasus adalah tindakan kompresi bimanual dan tindakan ballon tamponade. Keberhasilan dari tindakan ini dapat menekan morbiditas, mencegah tindakan operasi agresif, dan mempertahankan fertilitas. Tindakan BLynch dilakukan pada sebagian responden yaitu sebanyak 22 responden (59,5\%) sedangkan ligasi arteri dilakukan hanya pada sangat sedikit responden sebanyak 2 responden (5,4\%). Tindakan akhir dari penanganan kasus atonia uteri adalah histerektomi yang hanya dilakukan pada sebagian kecil responden yaitu sebanyak 9 responden (24,3\%) sebagai tindakan operatif invasive yang menyebabkan hilangnya fertilitas dengan tujuan life-saving. Proporsi penanganan dengan tindakan histerektomi pada kelompok kontrol lebih besar dibandingkan dengan kelompok kasus yaitu sebesar 68,6\%. Hal ini karena sebagian besar kasus dari kelompok kontrol merupakan kasus plasenta akreta, perkreta, dan ruptur uteri yang penanganannya cenderung berupa tindakan operasi agresif yaitu histerektomi [Tabel 2]. Seluruh variabel pada penelitian ini memiliki $20 \%$ sel dengan nilai harapan kurang dari 5 sehingga uji yang digunakan adalah Fisher Exact. Nilai kemaknaan hubungan ditunjukkan bila p value $<0,05$. Berdasarkan hasil uji statistik didapatkan hanya satu variabel yang terbukti memiliki hubungan bermakna dengan variabel dependen, yaitu variabel distensi uterus berlebih karena memiliki $p$ value $<0,05$. Analisis bivariat antara distensi uterus berlebih dengan kejadian atonia uteri menghasilkan $\mathrm{p}$ value 0,036 yang berarti terdapat hubungan bermakna dengan OR sebesar 4,423 (95\% CI 1,023-27,267). Ibu hamil yang mengalami distensi uterus berlebih seperti pada kasus gemelli, makrosomia dan polihidramnion memiliki risiko 4,423 kali lebih besar untuk terjadi atonia uteri dibandingkan dengan ibu hamil yang tidak mengalami distensi uterus berlebih. Variabel lain yaitu variabel umur, paritas, percepatan persalinan, dan partus lama tidak berhasil dibuktikan hubungannya dengan kejadian atonia uteri secara statistik. Seluruh variabel tersebut memiliki $\mathrm{p}$ value $>0,05$ sehingga dapat diartikan bahwa keempat variabel tersebut tidak memiliki hubungan bermakna dengan kejadian atonia uteri [Tabel 3].

\section{PEMBAHASAN}

Hasil analisis univariat mengungkapkan bahwa sebagian besar responden pada kelompok kasus penelitian ini memiliki pendidikan di tingkat SMA yang merupakan pendidikan lanjut, memiliki 
Tabel 2. Karakteristik Tindakan Penanganan Perdarahan Postpartum (n=72)

\begin{tabular}{|c|c|c|c|c|}
\hline \multirow{3}{*}{ Variabel } & \multicolumn{4}{|c|}{ Tindakan Penanganan } \\
\hline & \multicolumn{2}{|c|}{ Kasus } & \multicolumn{2}{|c|}{ Kontrol } \\
\hline & $n=37$ & $\%$ & $n=35$ & $\%$ \\
\hline \multicolumn{5}{|c|}{ Pemberian Uterotonika } \\
\hline Tidak & 1 & 2,7 & 18 & 51,4 \\
\hline $\mathrm{Ya}$ & 36 & 97,3 & 17 & 48,6 \\
\hline \multicolumn{5}{|c|}{ Pemberian Injeksi Asam Traneksamat } \\
\hline Tidak & 6 & 16,2 & 9 & 25,7 \\
\hline $\mathrm{Ya}$ & 31 & 83,8 & 26 & 74,3 \\
\hline \multicolumn{5}{|c|}{ Kompresi Bimanual } \\
\hline Tidak & 36 & 97,3 & 34 & 97,1 \\
\hline Ya & 1 & 2,7 & 1 & 2,9 \\
\hline \multicolumn{5}{|c|}{ Ballon Tamponade } \\
\hline Tidak & 34 & 91,9 & 33 & 94,3 \\
\hline Ya & 3 & 8,1 & 2 & 5,7 \\
\hline \multicolumn{5}{|l|}{ B-Lynch } \\
\hline Tidak & 15 & 40,5 & 35 & 100 \\
\hline $\mathrm{Ya}$ & 22 & 59,5 & 0 & 0 \\
\hline \multicolumn{5}{|c|}{ Ligasi Arteri } \\
\hline Tidak & 35 & 94,6 & 24 & 68,6 \\
\hline $\mathrm{Ya}$ & 2 & 5,4 & 11 & 31,4 \\
\hline \multicolumn{5}{|c|}{ Histerektomi } \\
\hline Tidak & 28 & 75,7 & 11 & 31,4 \\
\hline $\mathrm{Ya}$ & 9 & 24,3 & 24 & 68,6 \\
\hline \multicolumn{5}{|c|}{ Trachelektomi } \\
\hline Tidak & 37 & 100 & 30 & 85,7 \\
\hline $\mathrm{Ya}$ & 0 & 0,0 & 5 & 14,3 \\
\hline \multicolumn{5}{|l|}{ Curetage } \\
\hline Tidak & 37 & 100 & 32 & 91,4 \\
\hline $\mathrm{Ya}$ & 0 & 0 & 3 & 8,6 \\
\hline
\end{tabular}

pekerjaan, serta hampir seluruhnya memiliki paritas $<5$. Penelitian terdahulu mengungkapkan bahwa ibu yang memiliki pendidikan tinggi, bekerja, dan tinggal di perkotaan akan memanfaatkan pelayanan kesehatan maternal secara teratur (6) termasuk didalamnya pelayanan keluarga berencana untuk mengatur kelahiran. Penelitian lain menyatakan bahwa ibu yang memiliki tingkat pengetahuan tinggi memiliki kemungkinan cakupan pelayanan Antenatal Care (ANC) yang lebih lengkap 9,250 kali lebih tinggi daripada ibu yang tingkat pengetahuannya rendah (7).

Cara persalinan responden pada kelompok kasus sebagian besar $(67,6 \%)$ dengan cara sectio caesarea. Pada tindakan sectio caesarea umum terjadi kehilangan darah yang lebih banyak dibandingkan dengan partus pervaginam. Perdarahan tersebut diperberat dengan adanya keadaan patologi yang menjadi indikasi dilakukannya sectio caesarea seperti pada kasus kelainan plasentasi (plasenta akreta, inkreta, dan perkreta), serta keterkaitannya dengan risiko anastesi. Selain itu, kemungkinan atonia uteri mejadi lebih besar sebagai akibat berkurangnya kemampuan miometrium berkontraksi selama periode refraktori (8). Tindakan sectio caesarea yang dilakukan pada pasien inpartu kala dua juga meningkatkan kejadian Haemorrhage Postpartum (HPP) berat, hal ini dikarenakan adanya avulsi pada pembuluh darah jalan lahir sebagai akibat dari penurunan bagian terendah janin. Tindakan sectio caesarea juga meningkatkan kejadian atonia uteri (9).
Hampir seluruh pasien yang mengalami kejadian atonia uteri mendapatkan terapi medikamentosa dengan proporsi responden yang mendapatkan oksitosin sebesar 97,3\% dan yang mendapatkan injeksi asam traneksamat sebesar 83,8\%. Masase uterus tidak dapat dijadikan sebagai profilaksis dari kejadian HPP, meskipun dapat dilakukan sebagai langkah awal dari penanganan HPP yang bertujuan untuk merangsang kontraksi. Pemberian uterotonika menjadi pilihan utama dalam kasus atonia uteri (3).

Terapi lain yang digunakan untuk menghentikan perdarahan postpartum adalah injeksi asam traneksamat. Pemberian injeksi asam traneksamat pada pasien sectio cesarea sangat efektif untuk mencegah kehilangan darah lebih dari $1000 \mathrm{ml}$, tapi tidak pada partus pervaginam. Mekanisme dari asam traneksamat berkaitan dengan anti fibrinolitik yang mencegah aktivasi dari plasmin (10). Pada kasus perdarahan yang tidak dapat dihentikan dengan medikamentosa dan tindakan konservatif lainnya seperti kompresi bimanual dan ballon tamponade dilakukan penanganan dengan cara operatif. Tindakan B-Lynch termasuk tindakan operatif yang sangat efektif untuk menghentikan perdarahan masif dengan tetap mempertahankan fungsi fertilitas pasien (Sabarudin et al., 2015).

Tindakan lain untuk menghentikan perdarahan postpartum adalah histerektomi. Histerektomi merupakan tindakan invasif dalam penanganan perdarahan postpartum masif. Pengambilan 
Tabel 3. Hasil Analisis Bivariat Faktor Risiko yang Berhubungan dengan Kejadian Atonia Uteri (n=72)

\begin{tabular}{|c|c|c|c|c|c|c|c|}
\hline \multirow{3}{*}{ Variabel } & \multicolumn{4}{|c|}{ Perdarahan Postpartum } & \multirow{3}{*}{ OR } & \multirow{3}{*}{$95 \% \mathrm{CI}$} & \multirow{3}{*}{$\mathbf{p}$} \\
\hline & \multicolumn{2}{|c|}{ Kasus } & \multicolumn{2}{|c|}{ Kontrol } & & & \\
\hline & $\mathrm{n}=37$ & $\%$ & $n=35$ & $\%$ & & & \\
\hline \multicolumn{8}{|l|}{ Umur } \\
\hline$\leq 35$ tahun & 28 & 75,7 & 21 & 60 & - & $0,153-1,478$ & 0,208 \\
\hline$>35$ tahun & 9 & 24,3 & 14 & 40 & & & \\
\hline \multicolumn{8}{|l|}{ Paritas } \\
\hline$\leq 5$ & 36 & 97,3 & 35 & 100 & - & - & 1,0 \\
\hline$>5$ & 1 & 2,7 & 0 & 0,0 & & & \\
\hline \multicolumn{8}{|l|}{ Distensi Uterus Berlebih } \\
\hline Tidak ada distensi uterus berlebih & 26 & 70,3 & 32 & 91,4 & 4,423 & $1,023-27,267$ & 0,036 \\
\hline Distensi uterus berlebih & 11 & 29,7 & 3 & 8,6 & & & \\
\hline \multicolumn{8}{|l|}{ Percepatan Persalinan } \\
\hline Tidak & 36 & 97,3 & 35 & 100 & - & - & 1,0 \\
\hline $\mathrm{Ya}$ & 1 & 2,7 & 0 & 0,0 & & & \\
\hline \multicolumn{8}{|l|}{ Partus Lama } \\
\hline Tidak & 30 & 81,1 & 32 & 91,4 & - & $0,503-16,086$ & 0,309 \\
\hline Ya & 7 & 18,9 & 3 & 8,6 & & & \\
\hline
\end{tabular}

keputusan ini dilakukan dengan pertimbangan yang matang dan atas rekendasi dari konsultan yang berpengalaman. Keputusan untuk melakukan histerektomi merupakan keputusan paling akhir dengan tujuan life-saving (1).

\subsection{Hubungan umur dengan kejadian atonia uteri}

Salah satu faktor risiko yang berhubungan dengan kejadian atonia uteri adalah adanya peningkatan umur maternal yaitu usia >35 tahun (11) Kecenderungan untuk hamil diatas usia 35 tahun banyak ditemukan di negara maju. Peningkatan usia ini berkaitan dengan meningkatnya angka morbiditas maternal akibat adanya kondisi medis yang menyertai seperti semakin meningkatnya kasus hipertensi dan diabetes gestasional (12).

Hipertensi kronis dalam kehamilan dapat berakibat pada peningkatan kejadian preeklampsia (PE) dan preeklampsia berat (PEB) sedangkan prevalensi diabetes dikaitkan langsung dengan meningkatnya kejadian obesitas (12). Obesitas meningkatkan kejadian perdarahan postpartum dan tromboembolik sebesar dua kali lipat (13). PEB berkaitan dengan penggunaan MgSO4 sebagai antikonvulsan yang menyebabkan terhambatnya penyerapan kalsium ke dalam sel dan menyebabkan gangguan kontraksi uterus (Sabarudin et al., 2015).

Hasil pada penelitian ini menunjukkan bahwa kejadian atonia uteri paling banyak ditemukan pada umur $\leq 35$ tahun $(75,7 \%)$ dan secara statistik tidak terdapat hubungan bermakna antara umur dengan kejadian atonia uteri ( $p$ value 0,208). Beberapa penelitian menyatakan bahwa tidak terdapat hubungan yang signifikan antara umur dengan kejadian perdarahan postpartum $(9,14)$. Umur responden yang mengalami atonia uteri pada penelitian Lisonkova et al. (2016) di Kanada juga sebagian besar berada di usia <35 tahun dengan proporsi sebesar $74,15 \%$ dari seluruh kelompok kasus yang berjumlah 383 responden dan memiliki $p$ value 0,07 .
Teori menyatakan bahwa peningkatan umur maternal berkaitan dengan terjadinya kemunduran fisik dan daya tahan tubuh ibu serta berkurangnya elastisitas organ reproduksi sehingga meningkatkan risiko komplikasi intrapartum (Rochjati, 2011). Terdapat penelitian yang menyatakan bahwa usia $\geq 35$ tahun berisiko 1,24 kali untuk terjadi perdarahan postpartum (15).

Kejadian atonia uteri pada penelitian ini diketahui tidak berhubungan dengan faktor peningkatan umur maternal melainkan dapat terjadi karena pengaruh dari faktor risiko lain. Data dari beberapa studi yang mempelajari keterkaitan antara peningkatan usia maternal dan terjadinya komplikasi kehamilan masih saling bertentangan, serta masih terdapat keraguan mengenai penyebab komplikasi kehamilan apakah disebabkan oleh peningkatan usia maternal atau dikarenakan kormibiditas. Batas usia yang menyebabkan terjadinya komplikasi kehamilan juga berbeda pada tiap penelitian, sehingga batas usia yang secara signifikan membawa hasil yang merugikan masih belum jelas (12).

\subsection{Hubungan paritas dengan kejadian atonia uteri}

Grande multipara menjadi faktor risiko terjadinya perdarahan postpartum karena atonia uteri. Istilah grande multipara awalnya digunakan untuk wanita multipara berisiko tinggi yang telah melahirkan lebih dari 7 kali (16). Pada penelitian ini grande multipara didefinisikan sebagai paritas $\geq 5$ dengan usia kehamilan $>20$ minggu baik janin lahir hidup maupun mati. Penentuan batasan paritas didasarkan pada laporan yang mengungkapkan bahwa peningkatan risiko komplikasi obstetri dimulai pada paritas 5 (16).

Hasil pada penelitian ini didapatkan bahwa hampir seluruh sampel kelompok kasus memiliki paritas $\leq 5$ dengan proporsi $97,3 \%$ dan $p$ value 1,0 sehingga tidak ada hubungan yang bermakna antara paritas dengan kejadian atonia uteri. Terdapat penelitian baik di Arab Saudi maupun di Uganda yang mengemukakan bahwa tidak terdapat hubungan 
yang bermakna antara faktor risiko grande multipara dengan kejadian HPP $(9,17)$.

Teori menjelaskan pada wanita grande multipara terdapat gangguan kontraksi dan retraksi miometrium yang disebabkan oleh bekas luka lama dari kehamilan terdahulu dan adanya gangguan vaskularisasi akibat arterisklerosis yang menyebabkan gangguan oklusi saat plasenta terlepas dan mengakibatkan terjadinya perdarahan postpartum karena atonia uteri (18). Penelitian Mgaya et al. (2013) di Tanzania mengenai keterkaitan grande multipara dengan peningkatan prevalensi komplikasi maternal dan neonatal menyatakan bahwa grande multipara berisiko 2 kali lebih tinggi dibandingkan dengan multipara untuk terjadi atonia uteri dengan OR 2,0 (95\% CI 0,7-5,7) (16).

Hasil pada penelitian ini tidak sejalan dengan teori yang ada. Hal ini dapat terjadi karena hampir seluruh $(84,72 \%)$ responden yang menjadi sampel penelitian ini berada pada tingkat SMA sebagai pendidikan lanjut dan sebagian besar $(69,44 \%)$ responden memiliki pekerjaan. Tingkat pendidikan dan status ekonomi berdampak pada kesadaran wanita dalam mengatur kehamilan dengan penggunaan kontrasepsi, serta meningkatkan kesadaran dalam menurunkan faktor risiko dengan memeriksakan kehamilan secara teratur dan mengakses pelayanan kesehatan yang berkualitas. Paritas $\geq 5$ dapat meningkatkan risiko komplikasi obstetri, namun tidak semua risiko disebabkan karena paritas, perlu ditinjau ulang mengenai riwayat persalinan dan medis sebelumnya (19).

4.3 Hubungan distensi uterus berlebih dengan kejadian atonia uteri

Distensi uterus berlebih terjadi pada kasus ibu hamil dengan makrosomia, gemelli, dan polihidramnion. Peregangan uterus yang terjadi akibat beberapa keadaan tersebut menjadi penyebab terjadinya atonia uteri. Pada penelitian ini terdapat hubungan bermakna antara faktor risiko distensia uterus berlebih dengan kejadian atonia uteri dengan $p$ value 0,036 dan OR 4,423 (95\% CI 1,023-27,267). Hasil penelitian ini sejalan dengan studi yang dilakukan oleh Nurchairina (2017) di Medan yang menyatakan bahwa terdapat hubungan bermakna antara variabel distensi uterus berlebih dengan kejadian atonia uteri dengan $p$ value 0,001 dan OR sebesar 4, 608 (20).

Penelitian (21) di Kanada menyatakan tidak ada hubungan antara polihidramnion ( $p$ value 0,33$)$ dan kehamilan kembar ( $p$ value 0,13 ) dengan kejadian atonia uteri. Hasil yang tidak berkaitan ini dikarenakan keterbatasan kekuatan statistik dalam mencari asosiasi antara kejadian yang relatif jarang seperti pada kasus polihidramnion dan kehamilan kembar.

Pada kehamilan normal miometrium mengalami diferensiasi sel, yang mana serangkaian adaptasi memungkinkan miometrium untuk mengalami proliferasi dan hipertrofi tanpa mengalami kontraksi karena kapasitas kontraktilitas dinonaktifkan. Keadaan tersebut memungkinkan pertumbuhan dan perkembangan hasil konsepsi juga bertambahnya cairan ketuban secara progresif. Kontraksi uterus secara lokal akan terjadi pada akhir kehamilan yang disebabkan karena adanya distensi uterus. Keadaan dimana terjadi peregangan uterus berlebih menyebabkan uterus tidak mampu beradaptasi pada peningkatan volume. Hal ini menyebabkan peningkatan reseptor oksitosin pada miometrium. Prostacyclin meningkatkan ekspresi gap-junction dan protein kontraktil (22) Peningkatan aktivitas regular pada uterus menyebabkan terjadinya kelelahan pada uteri yang menyebabkan atonia uteri pasca persalinan.

Distensia uterus berlebih menjadi variabel yang berhubungan dengan kejadian atonia uteri pada penelitian ini disebabkan kasus pada distensia uterus berlebih dapat menjadi keadaan patologis yang menjadi indikasi dilakukannya tindakan sectio caesarea sehingga berisiko kehilangan lebih banyak darah dan berisiko terjadi atonia uteri (8). Prevalensi kehamilan kembar $(18,9 \%)$ menjadi prevalensi yang lebih banyak dibandingkan dua kasus distensia lainnya diikuti prevalensi makrosomia $(8,1 \%)$ dan polihidramanion $(2,7 \%)$ dan dapat menjadi indikasi dilakukannya tindakan sectio caesarea. Makrosomia dan polihidramnion dapat disebabkan oleh faktor komorbiditas yaitu diabetes mellitus yang prevalensinya dikaitkan dengan kejadian obesitas yang semakin meningkat (12).

\subsection{Hubungan percepatan persalinan dengan kejadian atonia uteri}

Tindakan percepatan persalinan dilakukan pada kasus kemacetan pembukaan (arrest of dilatation) dan kemacetan penurunan (arrest of descent) akibat kontraksi yang buruk (Cunningham et al., 2013). Penggunaan oksitosin selama persalinan dapat menyebabkan hiperaktivitas dari uterus. Hiperaktivitas uterus meliputi abnormalitas pada frekuensi kontraksi/ hiperkinesis frekuensi (uterus berkontraksi lebih dari 5 kali dalam 10 menit), abnormalitas pada durasi kontraksi/ durasi hiperkinesis (lama kontraksi >120 detik), abnormalitas pada amplitudo/ hiperkinesis intensitas (amplitudo $>80 \mathrm{mmHg}$ ). Hiperaktivitas uterus ini berkaitan dengan kejadian atonia uteri sebagai penyebab perdarahan postpartum (23).

Berdasarkan data penelitian ini didapatkan bahwa tidak terdapat hubungan bermakna antara percepatan persalinan dengan kejadian atonia uteri dengan hasil uji Fisher Exact didapatkan $p$ value sebesar 1,0. Hasil penelitian ini sejalan dengan penelitian yang dilakukan oleh Sosa et al. (2011) pada 19 unit maternitas di Amerika Latin yang bertujuan untuk mengetahui hubungan antara penggunaan oksitosin selama kala I dan kala II persalinan dengan tingginya angka kejadian HPP pada pasien yang mendapatkan manajemen aktif kala III. Pada penelitian tersebut diketahui tidak ada hubungan antara induksi dan percepatan persalinan dengan kejadian perdarahan postpartum minor ( $p$ value sebesar 0,753 ) dan kejadian perdarahan postpartum 
mayor ( $p$ value sebesar 0,273 ), namun tidak diketahui baik besarnya dosis yang digunakan maupun durasi paparan.

Teori menjelaskan bahwa penggunaan oksitosin selama persalinan dapat menyebabkan terjadinya desentisasi pada reseptor oksitosin. Kosentrasi dari reseptor oksitosin di miometrium menjadi berkurang secara signifikan dan menyebabkan hilangnya sensitivitas dari miosit terhadap rangsangan dari oksitosin. Desentisasi reseptor ini menjadi penyebab dari atonia uteri (23). Penelitian yang sejalan dengan teori bahwa augmentasi persalinan menjadi faktor risiko terjadinya HPP adalah penelitian Loscul et al. (2016) di Perancis yang mengemukakan bahwa terdapat peningkatan risiko HPP pada primipara yang mendapatkan percepatan persalinan dengan interval <20 menit. Selain itu, penelitian yang dilakukan Ekin et al. (2015) di Turki menjelaskan bahwa percepatan persalinan menjadi faktor terkuat terjadinya HPP $\quad(\mathrm{OR}=3.32, \quad 95 \% \quad \mathrm{CI} \quad 2.05-$ 5.93; $p<0.001$ ) dan atonia uteri menjadi penyebab dari kasus HPP mayor $(\mathrm{OR}=2.72,95 \%$ CI $1.64-$ 4.55; $p<0.001$ ).

Hasil penelitian yang tidak sejalan dengan teori dapat terjadi karena terbatasnya sampel yang mendapat percepatan persalinan (proporsi sebesar 2,7\% pada kelompok kasus). Hal ini juga berkaitan dengan sangat sedikitnya responden yang mengalami partus lama (proporsi sebesar 18,9\% pada kelompok kasus) sebagai indikasi dari tindakan percepatan persalinan.

\subsection{Hubungan partus lama dengan kejadian atonia} uteri

Penyebab tejadinya partus lama antara lain adanya cephalopelvic disproportion (CPD), kelainan posisi janin, buruknya usaha mengedan kaena pengaruh sedasi, dan faktor kelelahan (Singh et al., 2018). Nyfløt et al. (2017) menyatakan bahwa persalinan lama dengan fase aktif $>12$ jam berisiko 2,44 kali untuk mengalami perdarahan postpartum hebat (4).

Kontraksi uterus secara terus menerus dalam jangka waktu yang lama pada persalinan lama membuat kemampuan kontraktilitas miometrium berkurang dan menyebabkan terjadinya atonia uteri (4). Hal ini sejalan dengan penelitian Tort et al. (2015) di Senegal dan Mali yang menyatakan bahwa persalinan lama berisiko 1,21 kali menyebabkan kejadian HPP (24). Penelitian lain yang juga mendukung adalah penelitian yang dilakukan Ekin et al. (2015) di Turki yang menyatakan bahwa persalinan lama berisiko 3,32 kali menyebabkan kejadian HPP berat $(\mathrm{OR}=3.32,95 \%$ CI 2.05-5.93; $p$ value $<0.001$ ) (25).

Berdasarkan hasil uji statistik didapatkan hasil bahwa tidak terdapat hubungan antara partus lama dengan kejadian atonia uteri pada penelitian ini $(p$ value 0,309). Proporsi responden dari kelompok kasus yang mengalami atonia uteri adalah sebesar $18,9 \%$ dan hasil uji statistik didapatkan 95\% CI $0,503-16,086$. Nilai interval mencakup angka 1 , hal ini dapat diartikan bahwa variabel partus lama bukan merupakan faktor risiko atau sampel yang diteliti kurang banyak. Jumlah sampel pada kasus yang jarang terjadi tidak dapat dikontrol oleh peneliti. Kejadian partus lama yang jarang dapat dipengaruhi oleh sistem rujukan yang efektif dan peningkatan kesadaran untuk mengakses pelayanan obstetri emergensi saat timbul komplikasi selama persalinan.

\section{KESIMPULAN}

Berdasarkan hasil analisis univariat didapatkan karakteristik ibu yang mengalami perdarahan postpartum akibat atonia uteri sebagian besar berada di usia reproduksi sehat, bekerja, dan bersalin secara sectio caesarea. Hampir seluruh responden memiliki tingkat pendidikan SMA, memiliki paritas $<5$, dan tidak memiliki riwayat HPP. Karakteristik lainnya mengenai tindakan penanganan diketahui hampir seluruh responden mendapatkan terapi medikamentosa berupa uterotonika dan injeksi asam traneksamat. Tindakan lanjut berupa tindakan operatif diketahui sebagian responden mendapatkan penanganan berupa tindakan B-Lynch dan hanya sebagian kecil responden yang mengalami histerektomi.

Hasil dari analisi bivariat dapat disimpulkan dari 5 faktor risiko yang diteliti hanya 1 faktor risiko yang memiliki hubungan bermakna dengan kejadian atonia uteri yaitu faktor distensia uterus berlebih sehingga disarankan agar masyarakat lebih meningkatkan kesadaran mengenai pentingnya preconceptual care, terutama untuk mencegah maupun mengurangi prevalensi obesitas maupun kondisi medis yang ada sebagai komorbiditas, sehingga faktor risiko atonia uteri dapat ditekan. Peningkatan ketepatan dan time response yang cepat dari tenaga medis juga diperlukan untuk dapat mencegah dampak buruk lainnya dari kasus perdarahan postpartum seperti terganggunya aspek psikologi dan sosial pada ibu yang mengalami histerektomi. Bagi peneliti selanjutnya diharapkan dapat meneliti lebih lanjut berbagai faktor risiko yang lebih spesifik yang berhubungan dengan kejadian atonia uteri serta keterkaitan pengaruh pemberian pelayanan saat ANC dan INC dengan keefektifan pengelolaan faktor risiko kejadian atonia uteri.

\section{UCAPAN TERIMA KASIH}

Peneliti mengucapkan terima kasih kepada seluruh responden, pihak RS, serta semua pihak yang telah membantu selama proses penelitian berlangsung.

\section{DAFTAR PUSTAKA}

1. Sebghati M, Chandraharan E. An update on the risk factors for and management of obstetric haemorrhage. Women's Heal. 2017;13(2):3440 .

2. Weeks A. The prevention and treatment of postpartum haemorrhage: What do we know, and where do we go to next? BJOG An Int J Obstet Gynaecol. 2015;122(2):202-10. 
3. Royal College of Obstetricians \& Gynaecologists. Prevention and Management of Postpartum Haemorrhage: Green-top Guideline No. 52. BJOG An Int J Obstet Gynaecol. 2016;124(5):e106-49.

4. Nyfløt LT, Stray-Pedersen B, Forsén L, Vangen S. Duration of labor and the risk of severe postpartum hemorrhage: A case-control study. PLoS One. 2017;12(4):1-10.

5. Butwick AJ, Carvalho B, El-Sayed YY. Risk factors for obstetric morbidity in patients with uterine atony undergoing Caesarean delivery. $\mathrm{Br} \mathrm{J}$ Anaesth. 2014;113(4):661-8.

6. Azhar K, Dharmayanti I, Ahmad N. Faktor Lingkungan Sebagai Pembentuk Indikator Status Pelayanan Kesehatan Maternal. J Ekol Kesehat. 2016;15(2):115-26.

7. Agustini N, Suryani N, Murdani P. Hubungan Antara Tingkat Pengetahuan IBu dan Dukungan Keluarga dengan Cakupan Pelayanan Antenatal di Wilayah Kerja Pukesmas Buleleng I. J Magister Kedokt Kel. 2013;1(1):67-79.

8. D.P. P, Carmen G, M. M, Loredana M. Postpartum Hemorrhage after Cesarean Delivery - Causes and Management Statistics of „Prof. Dr. Panait Sîrbu „ Hospital- Bucharest. ARS Medica Tomitana. 2014;20(1):30-4.

9. Ononge S, Mirembe F, Wandabwa J, Campbell OMR. Incidence and risk factors for postpartum hemorrhage in Uganda. Reprod Health. 2016;13(1):38.

10. Novikova. Tranexamic acid for preventing postpartum haemorrhage ( Review ) SUMMARY OF FINDINGS FOR THE MAIN COMPARISON. 2015;(6).

11. Moncrieff G. Postpartum haemorrhage: Aetiology and intervention. Br J Midwifery. 2018;26(4):224-31.

12. Mills TA, Lavender T. Advanced maternal age. Obstet Gynaecol Reprod Med. 2014;24(3):8590.

13. Oyston C, Rueda-Clausen CF, Baker PN. Current challenges in pregnancy-related mortality. Obstet Gynaecol Reprod Med. 2017;27(7):199205.

14. Nyfløt LT, Sandven I, Stray-Pedersen B, Pettersen S, Al-Zirqi I, Rosenberg M, et al. Risk factors for severe postpartum hemorrhage: A case-control study. BMC Pregnancy Childbirth. 2017;17(1):1-9.

15. Sheldon WR, Blum J, Vogel JP, Souza JP, Gülmezoglu AM, Winikoff B, et al. Postpartum haemorrhage management, risks, and maternal outcomes: findings from the World Health Organization Multicountry Survey on Maternal and Newborn Health. BJOG. 2014;121 Suppl:513.

16. Mgaya AH, Massawe SN, Kidanto HL, Mgaya HN. Grand multiparity: Is it still a risk in Grand multiparity: is it still a risk in pregnancy? 2013;(March 2014).

17. Alsammani M, Ahmed S. Grand Multiparity: Risk Factors and Outcome in a Tertiary Hospital: a Comparative Study. Mater Socio Medica. 2015;27(4):244.

18. Njoku CO, Abeshi SE, Emechebe CI. Grand Multiparity: Obstetric Outcome in Comparison with Multiparous Women in a Developing Country. Open J Obstet Gynecol. 2017;07(07):707-18.

19. Pooja V, Sangeeta RS. Trends in the Occurrence of Antenatal and Perinatal Complications with Increasing Parity. 2013;63(August):260-7.

20. Nurchairina. Hubungan overdistensi uterus dengan kejadian atonia uteri pada ibu post partum di sebuah rumah sakit di provinsi lampung. 2017;XIII(2):215-20.

21. S L. Atonic Postpartum Hemorrhage: Blood Loss, Risk Factors, and Third Stage Management. J Obstet Gynaecol Canada. 2016;38(12):10811090.e2.

22. Prata N, Fraser A, Huchko MJ, Gipson JD, Withers $\mathrm{M}$, Lewis S, et al. Women's empowerment and family planning: a review of the literature. J Biosoc Sci. 2017;49(6):713-43.

23. Rousseau A, Burguet A. Oxytocin administration during spontaneous labor: Guidelines for clinical practice. Chapter 5: Maternal risk and adverse effects of using oxytocin augmentation during spontaneous labor. J Gynecol Obstet Hum Reprod. 2017;46(6):509-21.

24. Tort J, Rozenberg P, Traoré M, Fournier $\mathrm{P}$, Dumont A. Factors associated with postpartum hemorrhage maternal death in referral hospitals in Senegal and Mali: A cross-sectional epidemiological survey. BMC Pregnancy Childbirth. 2015;15(1):1.

25. Ozturk E, van Iersel $M$, van Loon $K$, den Rooijen $\mathrm{C}$, van Dongen E, van Wijngaarden $\mathrm{R}$ de $\mathrm{L}$, et al. Interactive online learning on perioperative management of elderly patients. Am J Surg [Internet]. 2018;216(3):624-9. Available from: https://doi.org/10.1016/j.amjsurg.2018.01.071 